Article

\title{
Consolidated Bioprocess for Bioethanol Production from Raw Flour of Brosimum alicastrum Seeds Using the Native Strain of Trametes hirsuta Bm-2
}

\author{
Edgar Olguin-Maciel ${ }^{1}$, Alfonso Larqué-Saavedra ${ }^{2}$, Patricia E. Lappe-Oliveras ${ }^{3}$, \\ Luis F. Barahona-Pérez ${ }^{1}$, Liliana Alzate-Gaviria ${ }^{1}$, Rubí Chablé-Villacis ${ }^{1}$, \\ Jorge Domínguez-Maldonado ${ }^{1}$, Daniella Pacheco-Catalán ${ }^{1}{ }^{\circledR}$, Hector A. Ruíz ${ }^{4}$ and \\ Raúl Tapia-Tussell 1,*(D) \\ 1 Renewable Energy Department, Yucatan Center for Scientific Research, Merida 97302, Mexico; \\ edgar.olguin@cicy.mx (E.O.-M.); barahona@cicy.mx (L.F.B.-P.); lag@cicy.mx (L.A.-G.); \\ rubi.chable@cicy.mx (R.C.-V.); joe2@cicy.mx (J.D.-M.); dpacheco@cicy.mx (D.P.-C.) \\ 2 Natural Resource Department, Yucatan Center for Scientific Research, Merida 97205, Mexico; larque@cicy.mx \\ 3 Mycology Laboratory, Biology Institute, National Autonomous University of Mexico, Mexico 04510, Mexico; \\ lappe@ib.unam.mx \\ 4 Biorefinery Group, Food Research Department, Faculty of Chemistry Sciences, Autonomous University of \\ Coahuila, Saltillo 25280, Mexico; hector_ruiz_leza@uadec.edu.mx \\ * Correspondence: rtapia@cicy.mx; Tel.: +52-999-9300760
}

Received: 27 August 2019; Accepted: 7 October 2019; Published: 23 October 2019

\begin{abstract}
Consolidated bioprocessing (CBP), which integrates biological pretreatment, enzyme production, saccharification, and fermentation, is a promising operational strategy for cost-effective ethanol production from biomass. In this study, the use of a native strain of Trametes hirsuta (Bm-2) was evaluated for bioethanol production from Brosimum alicastrum in a CBP. The raw seed flour obtained from the ramon tree contained $61 \%$ of starch, indicating its potential as a raw material for bioethanol production. Quantitative assays revealed that the Bm-2 strain produced the amylase enzyme with activity of $193.85 \mathrm{U} / \mathrm{mL}$. The Bm-2 strain showed high tolerance to ethanol stress and was capable of directly producing ethanol from raw flour at a concentration of $13 \mathrm{~g} / \mathrm{L}$, with a production yield of $123.4 \mathrm{~mL} / \mathrm{kg}$ flour. This study demonstrates the potential of T. hirsuta Bm-2 for starch-based ethanol production in a consolidated bioprocess to be implemented in the biofuel industry. The residual biomass after fermentation showed an average protein content of $22.5 \%$, suggesting that it could also be considered as a valuable biorefinery co-product for animal feeding.
\end{abstract}

Keywords: consolidated bioprocess; biofuels; starch; $\alpha$-amylase; white rot fungi

\section{Introduction}

The production of bioethanol for the transport sector is considered an important and necessary measure for reducing the dependence of modern society on fossil energy. Nowadays, fossil fuels cover $90 \%$ of the growing demand for energy. Unfortunately, with the current rate of fossil fuel consumption, it is expected that reserves will be exhausted within the next 40 to 50 years. More importantly, the burning of fossil fuels contributes to global warming due to greenhouse gas emissions, causing climate change, a rise in sea levels, loss of biodiversity, and urban pollution [1-3]. Among the alternative fuels options, bioethanol offers an immediate solution because it does not require to modify the current transport infrastructure. The use of bioethanol can reduce oil consumption as well as environmental pollution. Production and consumption of ethanol have been promoted through subsidies, mandates, and financing for research, and in fact, more than 64 countries have participated in various programs to 
use bioethanol as their main source of fuel. Ethanol blends vary depending on the country, containing from as low as 5\% (E5) to 100\% bioethanol (E100) [4-7].

The growing global demand for bioethanol requires the use of alternative sources of raw materials to complement sugar cane and cornstarch, which are the main raw materials used to produce it. Starch crops are widely used for bioethanol production because of their worldwide availability, easy conversion, and high ethanol yield. These raw materials include cereals $(60 \%-80 \%$ starch), tubers and roots $(60 \%-90 \%)$, legumes ( $25 \%-50 \%)$, and green and immature fruits (up to $70 \%$ starch) [2].

Conventionally, ethanol production from starch consists of several stages. Starch is subjected to a gelatinization process followed by a liquefaction step where starch is converted to dextrins and smaller molecules by the action of bacterial thermostable amylases at high temperatures $\left(95-105^{\circ} \mathrm{C}\right)$ and $\mathrm{pH}$ values between 6 and 6.5. This step is followed by saccharification. The liquefied starch is cooled, $\mathrm{pH}$ is adjusted to $4-4.5$, temperatures to $60-65^{\circ} \mathrm{C}$, and a fungal glucoamylase is added to hydrolyze the oligosaccharides to glucose. The liquefaction and saccharification stages represent about $40 \%-50 \%$ of the total energy used during starch-based ethanol production [8-10].

Owing to this technical complexity and the economic implications of this approach, other biological alternatives have been investigated, such as simultaneous saccharification and fermentation (SSF) and consolidated bioprocessing (CBP). The latter is a promising strategy for effective ethanol production, since it employs only one type of microorganism that is capable of both producing the enzymes to hydrolyze the biomass and converting sugars into ethanol [11,12]. This strategy has the potential of lowering the cost and enhancing the efficiency of bioethanol production, as compared to methods based on separate hydrolysis and fermentation. To achieve a cost-effective conversion of starch to bioethanol it is also worth considering the valorization of the by-products from this process. They are a rich source of protein, fiber, fat, vitamins, and minerals that can be used (wet or dried) as a component of livestock forage [11-14]. However, a large-scale techno-economic analysis of consolidated bioprocessing has been scarcely reported in the literature [15].

CBP requires the selection of suitable microorganisms, and bacteria and yeasts such as Clostridium thermocellum and Scheffersomyces shehatae $[14,16]$ have been the primary candidates for CBP research $[17,18]$. Fungi have not been widely proposed as CBP microorganisms, but several natural filamentous fungi have also been reported as directly converting cellulose to ethanol, including the genera Aspergillus, Rhisopus, Monilia, Neurospora, Fusarium, and Trichoderma [19]. Basidiomycetes, also known as wood-rotting fungi, are considered primary agents of plant litter decomposition in terrestrial ecosystems. Furthermore, some basidiomycetes produce alcohol dehydrogenases, thus allowing the production of wine using a mushroom [20]. In this regard, some wood-decaying basidiomycete fungi were reported to produce ethanol from hexoses, pentose, starch, wheat bran, and rice straw. These results indicate that white-rot fungi are good candidates for bioethanol production from woody biomass [19,21-24].

In this work, the use of the Bm-2 strain of Trametes hirsuta is proposed in a CBP for bioethanol production using flour made from ramon or breadnut tree (Brosimum alicastrum) seeds as a substrate. Ramon is a forest tree native to Mesoamerica and the Caribbean and is widely distributed in México, In the Yucatán Peninsula, México, breadnut is found virtually in every backyard or garden of the Mayan families, with a production of $95.5 \mathrm{~kg}$ per tree per year. Nowadays, this seed is rarely used for human consumption among the population of the Yucatan Peninsula. This species has suitable characteristics for producing bioethanol, such as high productivity, tolerance to drought, and a starch content of $61 \%$ [25-27]. In a previous work, Olguin-Maciel et al. [28] obtained $214 \mathrm{~L}$ of ethanol per ton of flour using separate hydrolysis and fermentation (SHF) and Candida tropicalis in the fermentation process.

The aim of this works was to develop a CBP using ramon seed flour as raw material and T. hirsuta Bm-2 strain as the microorganism for the fermentation process. In addition, the strain's capacity to produce hydrolytic enzymes and its tolerance to ethanol were studied. 


\section{Materials and Methods}

\subsection{Raw Material}

B. alicastrum seeds were collected from different locations in the State of Yucatan, Mexico. The seeds were dried in a convection oven (Binder, Fed model $115^{\circledR}$, Tuttlingen, Germany) at $70{ }^{\circ} \mathrm{C}$ for $72 \mathrm{~h}$, after which the seed coats were mechanically separated, and the clean seeds were stored in a desiccator until milling. The ramon flour (RF) used in this work contained $75 \%$ of carbohydrates, of which $61 \%$ was starch, and $12.24 \%$ was total proteins [28].

\subsection{Fungal Strain and Cultivation Conditions}

The T. hirsuta Bm-2 strain (GQ280373) was isolated from decaying wood in Yucatan, Mexico, and its molecular identification was based on the analysis of Internal Trancribed Spacers of nuclear ribosomalDNA (ITS regions) [29]. The strain was maintained by periodic subculturing on $14 \% \mathrm{RF}$ plates. A mycelia suspension of T. hirsuta Bm- 2 was obtained by inoculating $2 \times 1 \mathrm{~cm}$-diameter dishes of mycelium after 5 days growth in a $250 \mathrm{~mL}$ Erlenmeyer flask containing $100 \mathrm{~mL}$ of yeast extract and starch (YS) liquid medium, $\mathrm{pH} 5$, which consisted of $(\mathrm{g} / \mathrm{L})$ : yeast extract, $4.0 ; \mathrm{MgSO}_{4} \cdot 7 \mathrm{H}_{2} \mathrm{O}, 0.5$; $\mathrm{K}_{2} \mathrm{HPO}_{4}, 1.0$; the starch was replaced with $\mathrm{RF}(15.0 \mathrm{~g} / \mathrm{L})$. The flask was incubated at $32 \pm 2{ }^{\circ} \mathrm{C}$ and $150 \mathrm{rpm}$ for 6 days. During this period, $\alpha$-amylase and laccase activities were evaluated every $24 \mathrm{~h}$. The biomass obtained was homogenized with the T18 digital ULTRA-TURRAX ${ }^{\circledR}$ by IKA ${ }^{\circledR}$ (Staufen, Germany). The resulting suspension was used as inoculum in the CBP.

\subsection{Enzyme Assay}

\subsubsection{Analysis of $\alpha$-amylase Activity}

To study the ability of the Bm-2 strain to hydrolyze soluble potato starch, (Sigma Aldrich, St Luis, MO, USA), Petri plates with YS solid medium were inoculated with a $1 \mathrm{~cm}$-diameter dish of mycelium grown for 5 days, incubated at $32 \pm 2{ }^{\circ} \mathrm{C}$, and evaluated (two different plates) every $48 \mathrm{~h}$ for 6 days. The plates were flooded with Lugol's iodine solution (Sigma Aldrich) to monitor the production of a starch degradation halos after iodine staining [30]. A pale-yellow zone around the mycelium indicated starch degrading activity.

The activity of $\alpha$-amylase was determined by a modified method, following Ahmed et al. [31]. The assay mixture consisted of $0.5 \mathrm{~mL}$ soluble starch as substrate $(1 \%$ in $0.1 \mathrm{M}$ sodium acetate buffer $\mathrm{pH} 5.0$ ) and $0.5 \mathrm{~mL}$ of crude extract. After incubation for $20 \mathrm{~min}$ at $40{ }^{\circ} \mathrm{C}$, the reaction was stopped by cooling the sample to $4{ }^{\circ} \mathrm{C}$. After cooling, starch hydrolysis was determined through glucose release by the Miller DNS method [32]. The amount of enzyme production was expressed as U/mL. A unit of enzyme activity was defined as the amount of enzyme that released $1 \mu \mathrm{g}$ of reducing sugar as glucose standard per minute under assay conditions.

\subsubsection{Analysis of Laccase Activity}

Petri dishes with malt extract $(2 \%)$ and agar (2\%) containing $5 \mathrm{mM}$ 2,2'-azino-bis (3-ethylbenzthiazoline-6-sulphonic acid (ABTS) were inoculated with a $1 \mathrm{~cm}$-diameter dish of mycelium grown for 5 days and incubated at $32 \pm 2{ }^{\circ} \mathrm{C}$ for 4 days. The formation of a dark-green halo on the plates indicated a positive extracellular laccase secretion [29].

Laccase activity in cell-free filtrates was measured at $40^{\circ} \mathrm{C}$ using ABTS. The assay mixture contained $1 \mathrm{M}$ sodium acetate buffer ( $\mathrm{pH} 4.5$ ) and $0.5 \mathrm{mM} \mathrm{ABTS}$ in a total volume of $1 \mathrm{~mL}$. The oxidation of ABTS was measured by the increase in absorbance at $420 \mathrm{~nm}$, as described by Johannes and Majcherczyk [33]. One enzyme unit (U) is defined as the amount of enzyme required to oxidize $1 \mu \mathrm{mol}$ of ABTS per min under assay conditions. The amount of enzyme production was expressed as $\mathrm{U} / \mathrm{mL}$. 


\subsection{Tolerance to Ethanol}

Tolerance to ethanol was evaluated by inoculating a $1 \mathrm{~cm}$-diameter dish of mycelium grown for 5 days on Petri dishes of yeast extract-malt extract agar medium (YMA), which consists of $(\mathrm{g} / \mathrm{L})$ : glucose, 18.0; yeast extract, 3.0; malt extract, 3.0; peptone, 5.0, and agar 20.0. Different concentrations of absolute ethanol were added in increments of $1 \%(6 \%-14 \%, v / v)$, and the plates were incubated at $32 \pm 2{ }^{\circ} \mathrm{C}$. The autoclaved medium was cooled to $45-50{ }^{\circ} \mathrm{C}$, and warm ethanol was added immediately before pouring. The plates were sealed with parafilm soon after setting of the agar and again after inoculation. The evaluation was done 10 days after inoculation [34].

\subsection{Consolidated Bioprocess Conditions}

Experiments were performed in $250 \mathrm{~mL}$ Erlenmeyer flasks capped with cotton plugs, which allowed the transfer of oxygen during the CBP. A suspension of RF $(100 \mathrm{~mL}, 14 \% w / v)$ in distilled water was prepared and autoclaved at $121^{\circ} \mathrm{C}$ for $15 \mathrm{~min}$ (Yamato Sterilizer model SM510, Tokyo, Japan). The samples were cooled to room temperature, inoculated using $1 \mathrm{~mL}$ of inoculum prepared as described in Section 2.2 above, and then incubated at $32 \pm 2{ }^{\circ} \mathrm{C}$ for 12 days in stationary conditions in a drying chamber (Binder, Fed model 115, Tuttlingen, Germany). Samples of $1.5 \mathrm{~mL}$ of the supernatant were then taken for analysis (glucose liberation, ethanol production, and assessment of enzyme activity) at various times $(0,48,96,144,192,240$, and $288 \mathrm{~h}$ ).

At the end of the CBP, the fungal mycelium was removed from the flask and washed with distilled water for three times. The liquid fraction and the residual RF were separated by centrifugation at $8000 \mathrm{rpm}$ for $10 \mathrm{~min}$. The recovered liquid was stored at $4{ }^{\circ} \mathrm{C}$ for further analysis. Both the recovered mycelium and the residual $\mathrm{RF}$ were dried at $60^{\circ} \mathrm{C}$ to a constant weight, ground, and sieved with a No. 40 mesh. The protein content was determined in the mycelium and in the residual RF [35], while starch was determined in the residual RF only [36]. All experiments were performed in triplicate.

\subsection{Concentration of Ethanol and Glucose}

All samples taken from CBP were filtered through a $0.2 \mu \mathrm{m}$ sterile membrane filter and analyzed for glucose and ethanol content by HPLC (1260 Infinity II, Agilent, Santa Clara, CA, USA). Chromatographic separation was performed using a Metacarb $87 \mathrm{H}$ column $300 \times 7.8 \mathrm{~mm}$ (Agilent) under the following conditions: mobile phase $\mathrm{H}_{2} \mathrm{SO}_{4}(0.005 \mathrm{M})$, flow rate $0.7 \mathrm{~mL} / \mathrm{min}$, and column temperature $60^{\circ} \mathrm{C}$. The system comprised a Jasco chromatograph 880-PU intelligent pump (Jasco, Tokyo, Japan) equipped with a Jasco 830-IR intelligent refraction index detector (Jasco) and a Jasco AS-2057 Plus intelligent autosampler (Jasco). The volume injected was $20 \mu \mathrm{L}$ per sample. Sugars and ethanol concentrations were determined on the basis of the calibration curves of these pure compounds [37].

The fermentation efficiency was calculated from the theoretical ethanol yield using Equation (1) [38].

$$
\text { Fermentation efficiency }=\frac{\text { Ethanol produced }\left(\frac{\mathrm{g}}{\mathrm{kg}} \mathrm{starch}\right)}{\text { Theorical yield }\left(\frac{\mathrm{g}}{\mathrm{kg}} \mathrm{starch}\right)} \times 100
$$

The theoretical yield of ethanol (567 gm/ $/ \mathrm{kg}$ starch) was calculated using Equation (2) [38].

$$
\text { Theoretical yield }(\mathrm{g} / \mathrm{kg} \text { starch })=(511 \mathrm{a} \times 1.11 \mathrm{~b})
$$

where:

$\mathrm{a}=$ theoretical yield $(\mathrm{g})$ of ethanol from $1.0 \mathrm{~kg}$ glucose [39].

$\mathrm{b}=$ yield of glucose $(\mathrm{kg})$ from $1.0 \mathrm{~kg}$ starch [39]. 


\subsection{Physical-Chemical Characterization}

Elemental analysis (C, H, N, and S) was carried out using a Thermo Scientific Elemental Analyzer Flash 2000 (Thermo Scientific, Waltham, MA, USA). The functional groups on the carbon surface were determined by Fourier transform infrared spectroscopy (FTIR) with a Bruker FT-IR Tensor II (Bruker, Ontario, ON, Canada). This analysis was carried out with the attenuated total reflection (ATR) accessory. Thermogravimetric analyses (TGA) of initial and final samples were carried out using a Perkin Elmer TGA 8000 (PerkinElmer, Walthman, MA, USA). A TG curve was obtained under a nitrogen atmosphere with a flow rate of $10 \mathrm{~mL} / \mathrm{min}$ and a heating rate of $10^{\circ} \mathrm{C} / \mathrm{min}$ from 50 to $700{ }^{\circ} \mathrm{C}$ with a sample mass of $10 \mathrm{mg}$ in a platinum pan. The mass loss rate in the derivative form (derivative thermogravimetry, DTG) was also calculated.

Morphological characterization was also carried out with a scanning electron microscope (SEM, model JSM-6360LV, JEOL, Tokyo, Japan). Dry flour samples were mounted on a metallic stub using double-sided adhesive tape coated with a $15 \mathrm{~nm}$ gold layer and observed at $20 \mathrm{kV}$. After bioprocessing, the samples were fixed in $2.5 \%$ glutaraldehyde in a $0.02 \mathrm{M}$ sodium phosphate buffer ( $\mathrm{pH} 7.1)$ for $48 \mathrm{~h}$ ( $24 \mathrm{~h}$ at room temperature and $24 \mathrm{~h}$ at $4{ }^{\circ} \mathrm{C}$ ). This was followed by six $30 \mathrm{~min}$ washes in a $0.02 \mathrm{M}$ sodium phosphate buffer at $4{ }^{\circ} \mathrm{C}$ and then dehydratation in graded ethanol series $(30 \%, 40 \%, 50 \%, 60 \%, 70 \%$, $85 \%, 95 \%$, and $100 \% v / v$, twice for $30 \mathrm{~min}$ ). For SEM analysis, the samples were critical-point dried in $\mathrm{CO}_{2}$. After fixation and dehydration, the samples were processed in the same way as the initial flour [40].

The concentration of phenols was determined in triplicate by the Folin-Ciocalteu method [41], at $740 \mathrm{~nm}$. The phenolic content of the samples was expressed as $\mathrm{mg}$ gallic acid equivalents.

\section{Results and Discussion}

\subsection{Enzyme Activity}

In a first approach, the ability of T. hirsuta Bm-2 to produce amylase, the main enzyme used in the hydrolysis of starch, was evaluated. Then, the production of laccase enzyme was studied, as Basidiomycota is recognized as the most relevant phylum regarding the secretion of laccases [42].

The amylase test in Petri plates with YSA medium resulted in clear halos around the mycelial growth of T. hirsuta Bm-2, after 6 days of cultivation (Figure 1b). A $38 \mathrm{~mm}$ diameter hydrolysis zone around the mycelium was measured; this was due to the extracellular production of amylase. The amylase enzyme is produced by many microorganisms, and the Bacillus genus is considered to be the main source of this enzyme for commercial purposes. In the case of fungi, the reports are limited to a few species. The fungal sources are limited to terrestrial isolates, mostly Aspergillus and Penicilium [43]. In the case of Basidiomycete species, there are few reports of the production of this type of amylolitic enzymes, because these species are mainly used for their recognized capacity for ligninolitic enzyme production. However, the production of enzymes is influenced by the components of the medium, and amylase is induced in the presence of starch or its hydrolytic products such as dextrins and maltose [44,45], which are present in RF. 


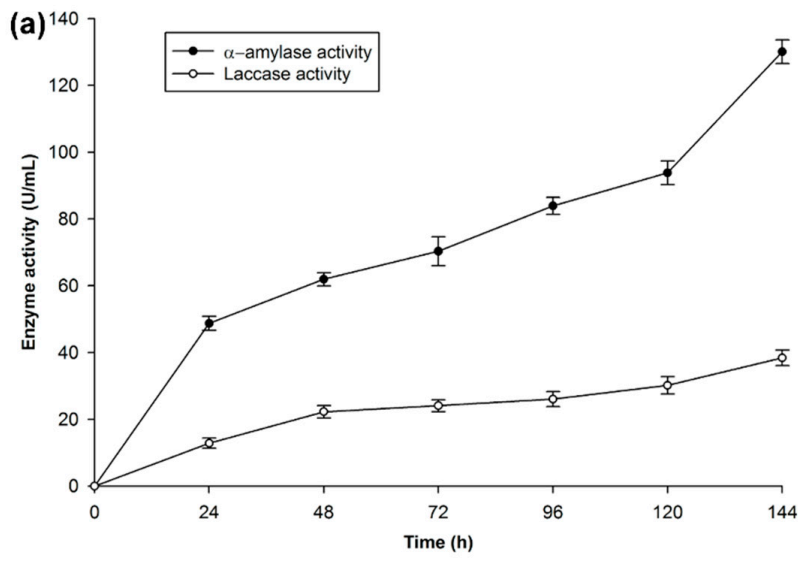

(b)

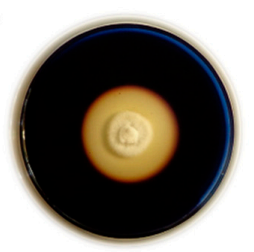

(c)

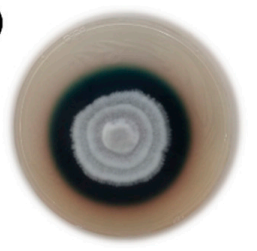

Figure 1. Test of the enzyme activity of the Trametes hirsuta Bm-2 strain. (a) Quantitative activity of laccase and $\alpha$-amylase enzymes, (b) screening for amylolitic activity in plates incubated at $32{ }^{\circ} \mathrm{C}$ for $144 \mathrm{~h}$, (c) screening for laccase activity in plates incubated at $32{ }^{\circ} \mathrm{C}$ for $96 \mathrm{~h}$. The results are represented as the mean \pm standard deviation of three parallel measurements $(n=3)$.

Figure 1c shows the characteristic dark-green halo that results from the oxidation of the ABTS indicator. The coloration around the mycelial growth indicates extracellular laccase activity in accordance with the work done on this strain $[29,41]$. T. hirsuta belongs to a small group of Basidiomycetes, known as white-rot fungi, which possess the unique ability to break down lignocellulosic biomass. This process can be accomplished through the production of two enzymatic systems: (1) A hydrolytic system, which produces cellulases and hemicellulases that degrade polysaccharides; and (2) An oxidative ligninolytic system, which degrades lignin and opens the phenyl rings. Lignin peroxidase, manganese peroxidase, and laccase are the key enzymes [46].

The profiles of extracellular enzymatic activities during cultivation of T. hirsuta Bm-2 are shown in Figure 1a.

The production of $\alpha$-amylase reached its maximal level on the sixth day of growth, with approximately $135 \mathrm{U} / \mathrm{mL}$ of activity. This agrees with reference [47], who mentioned that amylase from a fungal source is normally produced after 3-7 days of incubation. There are a few reports of amylase production by Basidiomycetes, e.g., the amilolytic capacity of $T$. hirsuta has been qualitatively determined [21,48], as well as an enzymatic activity of $267 \mathrm{U} / \mathrm{g}$ for amylase in the Basidiomycete Ganoderma lucidum [49]. However, comparisons of the $\alpha$-amylase activity level are very difficult due to the different methodologies used to determine the enzyme activity, the different manners of reporting the enzyme concentration, and the different ways of defining the units used to measure enzyme activity [44].

The ability of T. hirsuta to produce $\alpha$-amylase extracellularly can contribute to establishing CBP production of bioethanol from starch material. It has the advantage of reducing the production costs with respect to the use of commercial enzymes, such as the energy costs, since these enzymes show their greatest activity in the same temperature range as that optimal for the growth of $T$. hirsuta, which produces them, in this case $32 \pm 2{ }^{\circ} \mathrm{C}$.

Laccase activity was $40 \mathrm{U} / \mathrm{mL}$, as reported previously [29] for the same strain. This value is low, considering the recognized ability of this type of fungus to produce ligninolitic enzymes, as mentioned above. However, it should be pointed out that the medium used to prepare the inoculum in this study was starch-rich and induced the production of amylase, while for laccase induction in Basidiomycetes, aromatic compounds such as phenols associated with lignin are used, as mentioned in previous studies. In the presence of compounds such as ferulic acid, vanilline, guaiacol, and wheat bran, Tapia-Tussell et al. [41] and Zapata-Castillo et al. [50] obtained high lacasse activities of 2543.7 and $2496 \mathrm{U} / \mathrm{mL}$, respectively. When they used low concentrations of these inductors, they reported low laccase activity ( 234.7 and $178 \mathrm{U} / \mathrm{mL}$, respectively). In this study, the low laccase activity was due to the low concentrations of free phenols $(2.90 \mathrm{mg} / \mathrm{g}$ of $\mathrm{RF})$. 


\subsection{Tolerance to Ethanol}

During the fermentation process, the ethanol produced can inhibit the growth and viability of microorganisms by altering the cell membrane as well as the protein receptors associated with it [51,52]. Most studies related to ethanol tolerance have been carried out on yeasts. However, there is evidence of an ethanol effect on fungi. In Phanerochaete chrysosporium, ethanol influenced the morphology of the cell wall and led to decreased pellet diameter and fungal biomass net weight [53]. In Trichoderma resei cultures, the presence of ethanol $(0.5 \%-2 \% v / v)$ hindered the secretion of cellulases, which are important enzymes for cellulose hydrolysis [53]. In Figure 2, the growth of T. hirsuta Bm-2 at concentrations of $0 \%, 10 \%, 11 \%, 12 \%, 13 \%$, and $14 \% v / v$ of ethanol after 10 days of incubation is shown. T. hirsuta $\mathrm{Bm}-2$ was able to grow vigorously at concentrations up to $10 \% v / v$, similar to what observed without alcohol. A $50 \%$ growth could be observed at ethanol concentrations of $11 \%$ and $12 \% v / v$, compared to the control. An incipient growth at a concentration of $13 \% v / v$ indicated that $T$. hirsuta $\mathrm{Bm}-2$ was resistant to this concentration but was not able to grow adequately. At an ethanol concentration of $14 \%$, complete growth inhibition of the fungus occurred. These results are similar to those found in the literature [22], which report the growth of the Basidiomycete Phanerochaete chrysosporium in the presence of ethanol concentrations of $12.2 \%$. The level of ethanol tolerance of T. hirsuta obtained in this work is similar to that of Saccharomyces cerevisiae, which possesses a high tolerance to ethanol (concentrations up to $14 \%$ ) and is traditionally used for the production of alcoholic beverages and bioethanol [54,55].
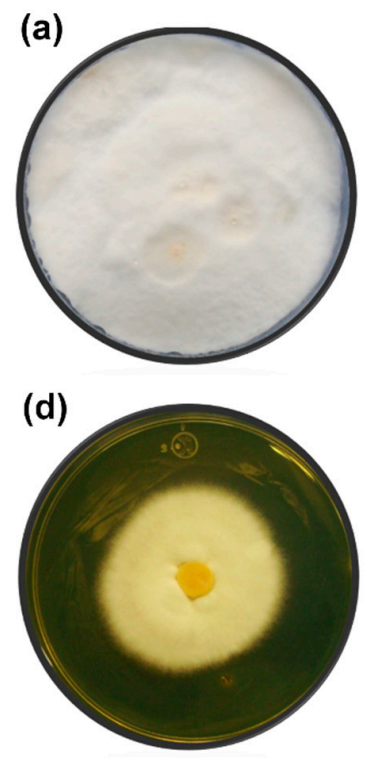

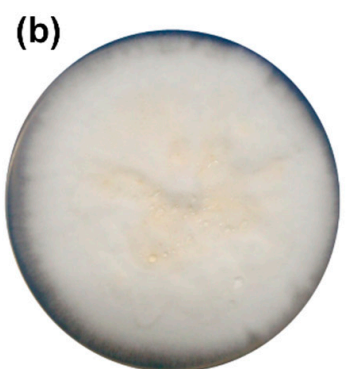

(e)

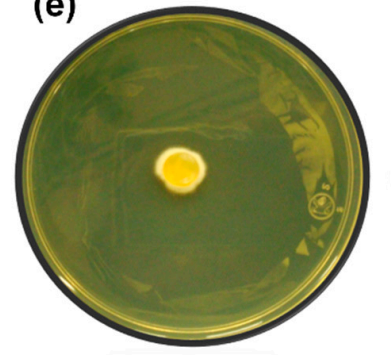

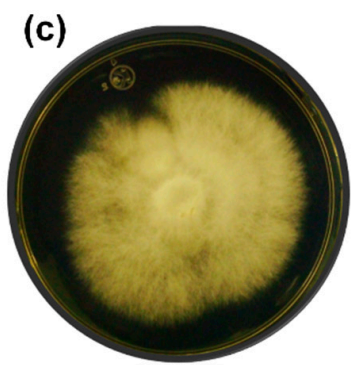

(f)

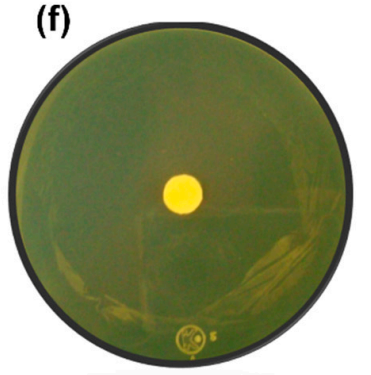

Figure 2. Ethanol tolerance test in solid yeast extract-malt extract agar medium (YMA) medium during10 days of incubation at $32{ }^{\circ} \mathrm{C}$. (a) Control without ethanol, (b) $10 \%(v / v)$ ethanol, (c) $11 \%(v / v)$ ethanol, (d) $12 \%(v / v)$ ethanol, (e) 13\% (v/v) ethanol, and (f) $14 \%(v / v)$ ethanol. The experiments were performed in triplicate.

\subsection{Ethanol Production by CBP with T. hirsuta Bm-2}

Firstly, RF loads within a range of $10 \%$ to $20 \%(w / v)$ were used. It was found that at RF loads of $16 \%, 18 \%$, and $20 \% w / v$, the fungus started growing very slowly, taking up to 8 days after inoculation to cover the substrate surface. In the case of the $10 \%$ and $12 \%$ loads, the fungus did not grow adequately because of the aqueous consistency of the medium. The fungus grew adequately at $14 \%$ concentration and covered the substrate surface within 5 to 6 days after inoculation, allowing a reduction of CBP time.

Figure 3a shows the profile of $\alpha$-amylase activity during the development of CBP. The activity increased for $192 \mathrm{~h}$, with a peak activity of $193.85 \mathrm{U} / \mathrm{mL}$ and then decreased at the end of the process. The slight decrease in the activity may be associated with an increment in ethanol concentration, since this molecule binds to the non-catalytic region of the enzyme, causing changes in its spatial 
configuration. However, not all enzymes are affected by ethanol in the same way. On some enzymes, such as $\beta$-glucosidase, ethanol even has a positive effect [53]. The inhibition of an enzyme by ethanol depends on other culture conditions, such as temperature and time. Sanchez et al. [44] mentioned that some authors attribute the decrease of amylase activity to a possible denaturation and/or decomposition of the enzyme due to the interaction with other components in the fermentation broth. Another factor related to a decrease in activity is starch consumption: low starch concentrations affect the induction of enzyme production, and enzymatic activity is affected by variations of the $\mathrm{pH}$. However, in this case, the $\mathrm{pH}$ had a constant value of 5.1 during the CBP.

(a)
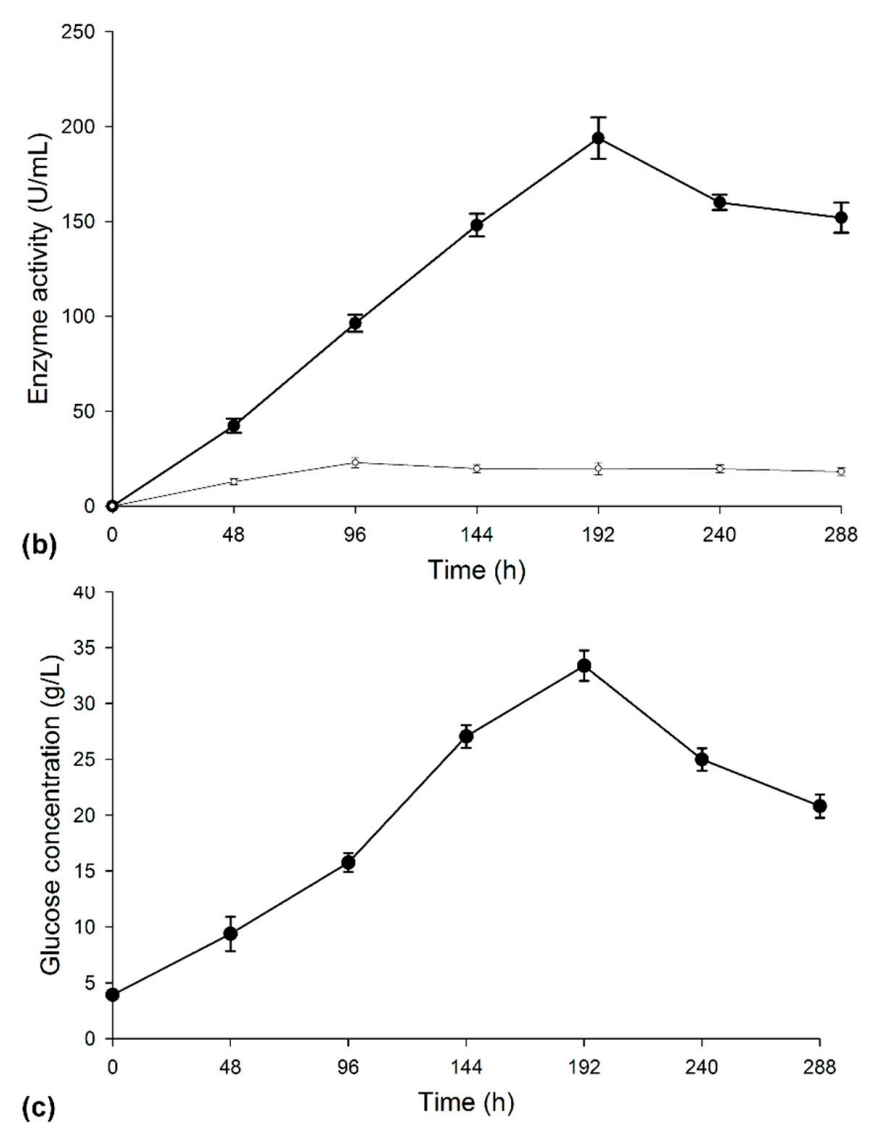

(c)

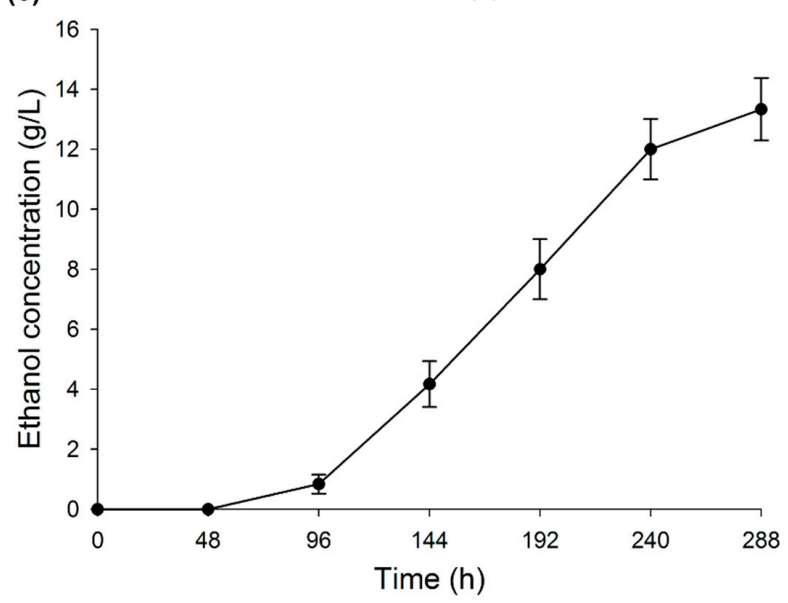

Figure 3. Changes during consolidated bioprocess. (a) $\alpha$-amylase and laccase activities, (b) glucose concentration, and (c) ethanol concentration. Results are represented as the mean \pm standard deviation of three parallel measurements $(n=3)$. 
The activity profile of the laccase enzyme can be observed in Figure 3a. After $96 \mathrm{~h}$, laccase activity reached $20 \mathrm{U} / \mathrm{mL}$ and remained constant until the end of the CBP. The laccase enzyme plays an important role in the depolymerization of the fibroproteic matrix that covers the ramon starch granules (Figure 4a). To verify this, a purified laccase extract [56] was applied to a gelatinized suspension at $20 \% w / v\left(\mathrm{RF} /\right.$ distilled water) under the following conditions: $40{ }^{\circ} \mathrm{C}$, sampling at 24 and $48 \mathrm{~h}, \mathrm{pH}$ 5.1, $300 \mathrm{U}$ of laccase $/ \mathrm{g}$ of RF, $150 \mathrm{rpm}$. The results showed a fragmentation of the proteic matrix in the RF, allowing the release of the starch granules (Figure $4 \mathrm{~b}$ ). The laccase enzyme did not have any effect on the starch granules, as the concentration of free sugars in the solution at 24 and $48 \mathrm{~h}$ was maintained at $4 \mathrm{~g} / \mathrm{L}$. In Figure $4 \mathrm{c}$, the RF at the end of the CBP is shown. The presence of mycelium indicates a vigorous growth of the fungus. Few starch granules remained at the end of the CBP, indicating a synergy between amylase and laccase enzymes. The starch granules were hydrolyzed by amylase after they were released from the flour matrix by laccase. This synchronous action of the two enzymes has recently been reported in the literature [57].
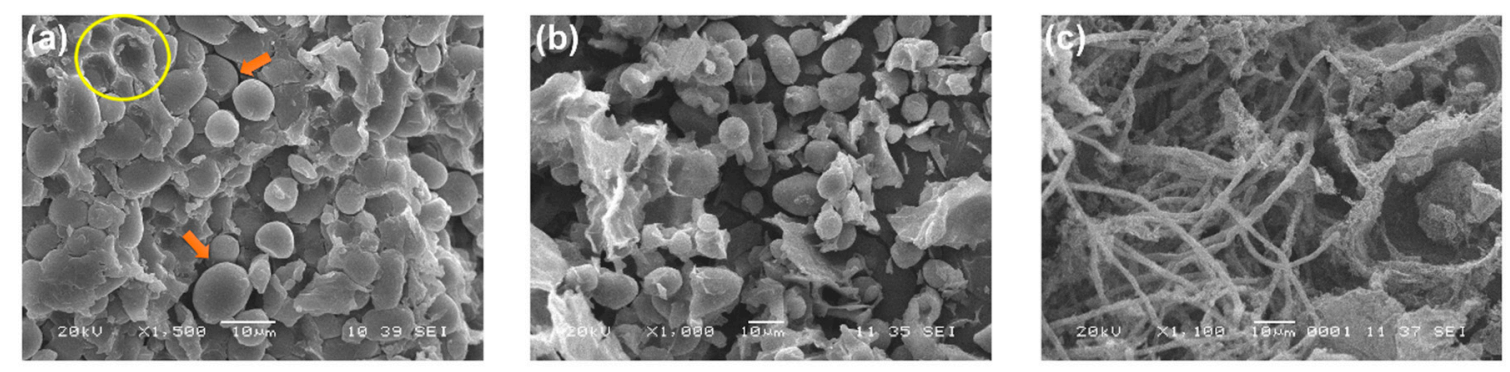

Figure 4. Scanning electron microscopy (SEM) of ramon flour. (a) without inoculation (b) treated with laccase extract, and (c) after 12 days of incubation at $32{ }^{\circ} \mathrm{C}$.

The glucose production profile (Figure $3 \mathrm{~b}$ ) was similar to that of the amylase activity. Glucose concentration was higher at $192 \mathrm{~h}(30 \mathrm{~g} / \mathrm{L})$ and then decreased to $20 \mathrm{~g} / \mathrm{L}$ when amylase activity began to lower, while the fungus consumed glucose. The remaining concentration of free glucose at the end of the CBP suggests the need for implementing an additional strategy, e.g., co-cultivation of the fungus with an adequate yeast and increase in the production of ethanol.

Few natives microorganism directly convert the substrate to ethanol. In this study, we evaluated T. hirsuta Bm-2 in the direct production of ethanol from raw RF. Some attempts of direct bioethanol production using various microorganisms are summarized in Table 1. S. cerevisiae remains one of the most used microorganisms for fermentation, because of its high ethanol-producing ability, high inhibitor tolerance, and advantageous generally-regarded-as-safe (GRAS) status. S. cerevisiae strains lacking starch-degrading ability have been genetically engineered to express the amylase genes. However, the use of recombinant yeast strains increases the production costs as well as the biological risks, as regulations require that the genetically engineered yeasts be physically contained in order to prevent their escaping into the environment [14]. The first three examples in Table 1 refer to S. cerevisiae strains modified to express amylolytic enzymes, which allows them to reach high ethanol yields in a relatively short time, especially the Y294 strains, which reaches concentrations of $45 \mathrm{~g} / \mathrm{L}$ in $144 \mathrm{~h}$ and thus offers an advantage with respect to native strains that generally require longer incubation periods. However, it should be noted that the fermentative tests on these microorganisms were performed in synthetic media with starch as a carbon source and, in the case of Y294 strains, commercial enzymes were introduced to perform hydrolysis. S. shehatae is a native strain that presents amylolytic enzymes production, ethanol tolerance, and fermentative capacity, which suggests to the authors that it is a suitable strain for one-step ethanol production using starch. Despite these characteristics, in this first attempt, the strain of S. shehatae JCM 18690 only hydrolyzed 50\% of the soluble starch present after 10 days of culture, perhaps because of a low enzymatic activity or culture conditions that the authors mentioned will be resolved in later works. 
Okamoto et al. [21] described the T. hirsuta ability to hydrolyze and ferment starch. In contrast to this work, these authors used a synthetic medium (medium T) where the carbon source was replaced by starch. In this work, instead, a complex raw material was used to obtain ethanol production, which began after $48 \mathrm{~h}$ of cultivation and reached a concentration of $13 \mathrm{~g} / \mathrm{L}$ at $288 \mathrm{~h}$ (Figure 3c). On the basis of these results, a production of $123.44 \mathrm{~mL}$ of ethanol per $\mathrm{kg}$ of $\mathrm{RF}$ was estimated. This value is $57.95 \%$ of that reported for this substrate in previous works using SHF with a native strain isolated from the seeds of B. alicastrum (C. tropicalis) and $84.35 \%$ compared with the value reported for a standard fermentation yeast (S. cerevisiae) [26]. Despite the low ethanol yield, it should be taken into consideration that the CBP makes the purchase of enzymes unnecessary, because the Bm-2 strain produces laccase and amylase. Another advantage is that only one organism was used for hydrolysis and fermentation of the flour. Finally, the whole process occurred within a temperature range of $32 \pm 2{ }^{\circ} \mathrm{C}$ in the same reactor, which allows a more efficient ethanol production. Similarly, no nitrogen source was added for $\mathrm{Bm}-2$ strain growth, nor any enzyme inductor or buffer solution to maintain adequate $\mathrm{pH}$ values. Additionally, the initial $\mathrm{pH}$ value of the substrate ranged between 5 and 5.5, hence no initial $\mathrm{pH}$ adjustment was necessary, since the fungus grows naturally at these $\mathrm{pH}$ values. At the end of the CBP, $10 \%$ and $30 \% w / w$ of mycelium and residual flour, respectively, remained in the medium. These residues could be considered co-products to be used as animal feed, since they contain $29 \%$ and $16 \%$ of protein, respectively, giving a residual biomass with an average of $22.5 \%$ of protein. These data demonstrate that CBP using T. hirsuta Bm-2 with RF as a substrate is a promising strategy towards the sustainable production of bioethanol.

Table 1. Ethanol production through consolidated bioprocessing (CBP).

\begin{tabular}{cccc}
\hline Substrate & Microorganism & Ethanol [g/L] & Referencia \\
\hline Corn starch & Saccharomyces cerevisiae Mnua1 & 9.03 after 240 d & {$[58]$} \\
Raw starch and glucose & S. cerevisiae Y294[AteA-GlaA] & 45.77 after 144 h & {$[59]$} \\
Raw starch and glucosa & S. cerevisiae Y294[GlaA-AteA] & 45.85 after $144 \mathrm{~h}$ & {$[59]$} \\
Soluble starch & Scheffersomyces shehatae JCM 18690 & 9.2 after 240 h & {$[14]$} \\
Starch & Trametes hirsuta & 9.1 after $96 \mathrm{~h}$ & {$[21]$} \\
Raw Ramon Flour & T. hirsuta Bm-2 & 13 after 288 h & This work \\
\hline
\end{tabular}

\subsection{Material Flow Balance}

For the CBP experiments, $13.3 \mathrm{~g}$ of RF (dry weight) were poured into $90.7 \mathrm{~mL}$ of distilled water. This mixture was sterilized, and a loss of $3.3 \mathrm{~g}$ was recorded. Once the mixture was cooled, $1 \mathrm{~mL}$ of inoculum $(1.3 \mathrm{~g})$ was added, initiating the CBP with a starting total weight of $102 \mathrm{~g}$. After completion of the CBP, $1.33 \mathrm{~g}$ of mycelium and $3.99 \mathrm{~g}$ of non-hydrolyzed RF (dry weight) were recovered. The liquid phase was $88.43 \mathrm{~mL}$ and was made up of $46.03 \mathrm{~mL}$ of supernatant, $10.5 \mathrm{~mL}$ from sampling, and $31.9 \mathrm{~mL}$ of water calculated from humidity values of the mycelium and residual $\mathrm{RF}$ ( $85 \%$ and $83 \%$, respectively). Also, $1.3 \mathrm{~g}$ of ethanol and $2 \mathrm{~g}$ of glucose were detected in the supernatant.

According to the biomass flow balance, there was a consumption of $68.8 \%$ of RF with respect to the initial substrate load. Table 2 shows the amounts of starch, protein, and other elements before and after the CBP. It was calculated that $5.51 \mathrm{~g}$ of starch (6.12 $\mathrm{g}$ of glucose) was consumed, which represented $67 \%$ hydrolysis of starch. From the glucose released during the process, $2.6 \mathrm{~g}$ was used for ethanol (calculated from the ethanol data reported above). This represents an efficiency of $28.2 \%$ with respect to the starch present in RF. In the supernatant, $2 \mathrm{~g}$ of free glucose was quantified, so it was calculated that the fungus, together with other RF compounds, used $1.1 \mathrm{~g}$ of glucose for growth. 
Table 2. Consumption analysis of the main components of ramon flour during CBP.

\begin{tabular}{cccc}
\hline Component & RF (Control) g & RF (12 Days after Inoculated) $\mathbf{g}$ & \% Material Consumed \\
\hline Starch & $8.11 \pm 0.67$ & $2.60 \pm 0.35$ & 67 \\
Protein & $1.63 \pm 0.44$ & $0.66 \pm 0.50$ & 59 \\
Others & $3.56 \pm 0.50$ & $0.88 \pm 0.34$ & 75 \\
\hline
\end{tabular}

\subsection{Physical-Chemical Characterization}

Analysis of the main components of initial and residual flour indicated that slight changes occurred in its chemical composition after CBP (Figure 5). Starch content showed a slight increase of 2 percentage points; the similarity of starch contents in the initial and the residual flour may be due to the fact that, being in stationary conditions, the enzymes were only active in the aqueous and semi-solid interface of the mixture. The protein content increased from $12.24 \%$ to $16 \%$, which can be attributed to the fact that parts of the mycelium, with high protein content, were deposited in the flour (Figure 3c) as well as to the presence of remnants of the enzymes released by the fungus. The content decrease of the third component of RF (fibers, ashes, phenols, etc.) can be attributed to the ability of the fungus to use the phenols present in RF through the action of the laccase enzyme. Part of the insoluble fiber could also be hydrolyzed by T. hirsuta, as it is able to produce cellulases, in agreement with previous studies reported by Castoldi et al. [46].

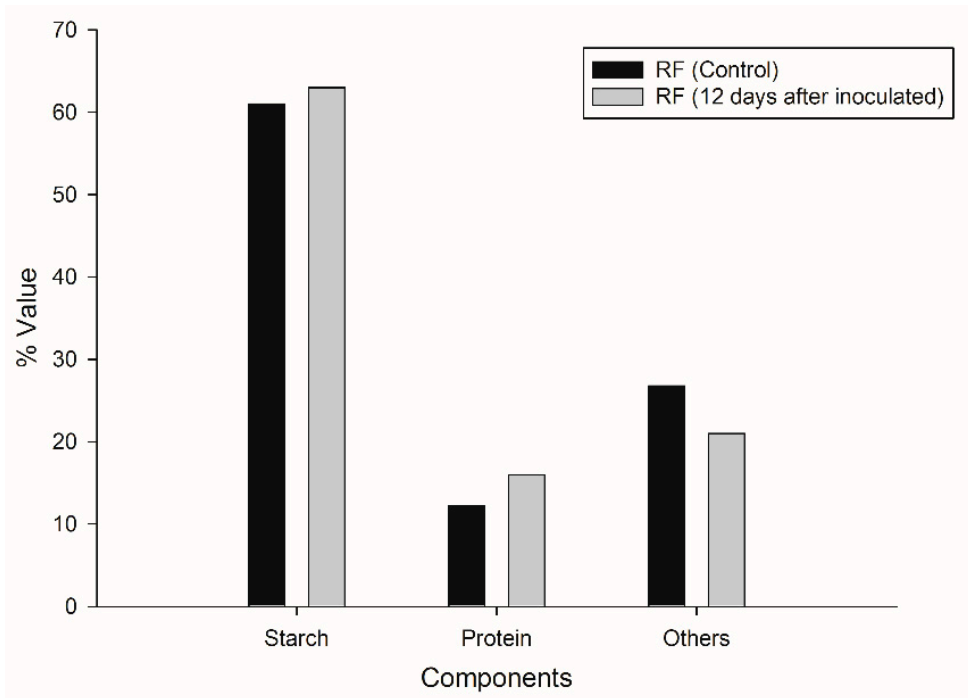

Figure 5. Comparative analyses of the principal components of the initial ramon flour (RF control) and the residual ramon flour (RF 12 days).

These slight changes in RF composition were confirmed by elemental analysis (Table 3), where a slight increase in nitrogen content was observed in the residual $\mathrm{RF}$, in accordance with the increase in protein.

Table 3. CHNS elemental analyses of the initial ramon flour and residual ramon flour.

\begin{tabular}{cccc}
\hline Sample & N (wt \%) & $\mathbf{C}(\mathbf{w t} \%)$ & H (wt \%) \\
\hline Initial RF & $2.04 \pm 0.10$ & $41.22 \pm 0.80$ & $6.41 \pm 0.01$ \\
Residual RF & $2.79 \pm 0.18$ & $41.87 \pm 0.16$ & $6.10 \pm 0.04$ \\
\hline
\end{tabular}

TGA analysis of initial and residual RF revealed that structural changes occurred during CBP (Figure 6). In order to carry out the analysis, three stages were selected. Stage I comprised temperatures from 20 to $140{ }^{\circ} \mathrm{C}$, at which the main events are water evaporation and volatilization of light biomass 
compounds. In Stage II (140 to $\left.340^{\circ} \mathrm{C}\right)$, decomposition of carbohydrates occurs [60]. In this stage, the presence of a double shoulder in the DTG curves of the residual RF indicates a partial enzymatic breakdown of the long amylose/amylopectin chains during the CBP. At Stage III (340 to $700{ }^{\circ} \mathrm{C}$ ), substances with high molecular weight, like polysaccharides, proteins, lipids, are degraded. In this stage, the effect of the enzymes produced by the fungus that degrade the polysaccharides of the fibroprotein matrix is observed, the shoulder disappearing between 400 and $500{ }^{\circ} \mathrm{C}$ in DTG curve coinciding with that observed in scanning electron microscopy in the fragmentation of this matrix.

(a)

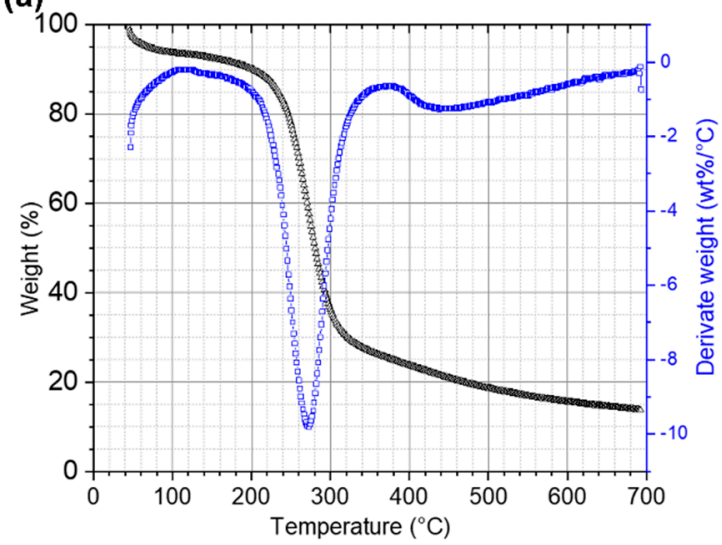

(b)

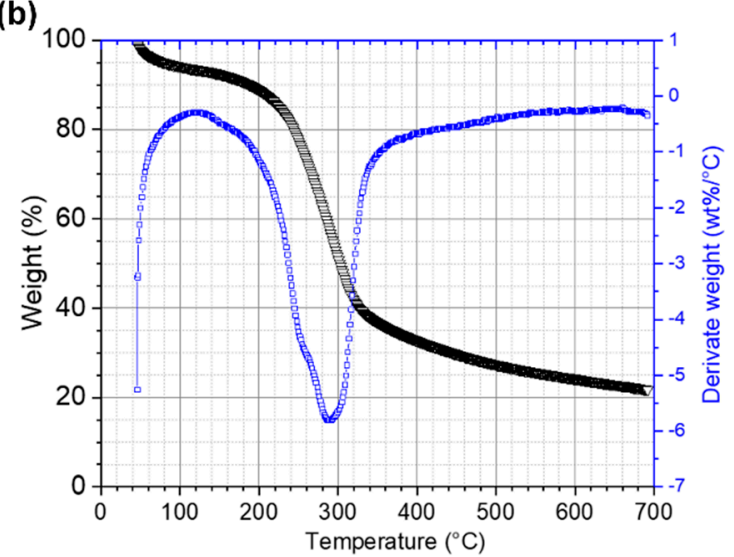

Figure 6. TGA and DTG curves of ramon flour. (a) RF control and (b) RF 12 days after inoculation.

FTIR spectra of RF before and after CBP are shown in Figure 7. These spectra had a similar pattern of absorption bands. The bands between 3700 and $3000 \mathrm{~cm}^{-1}$ can be attributed to a combination of $\mathrm{N}-\mathrm{H}$ stretching vibrations from the protein and the $\mathrm{H}-\mathrm{O}-\mathrm{H}$ stretching vibrations of condensed-phase water molecules $[61,62]$. Specifically, the peak at $3650 \mathrm{~cm}^{-1}$ is associated with the $\mathrm{N}-\mathrm{H}$ stretching from protein, and an increase in the intensity of this band in the residual RF can be observed. This result agrees with those of the elemental analysis mentioned above.

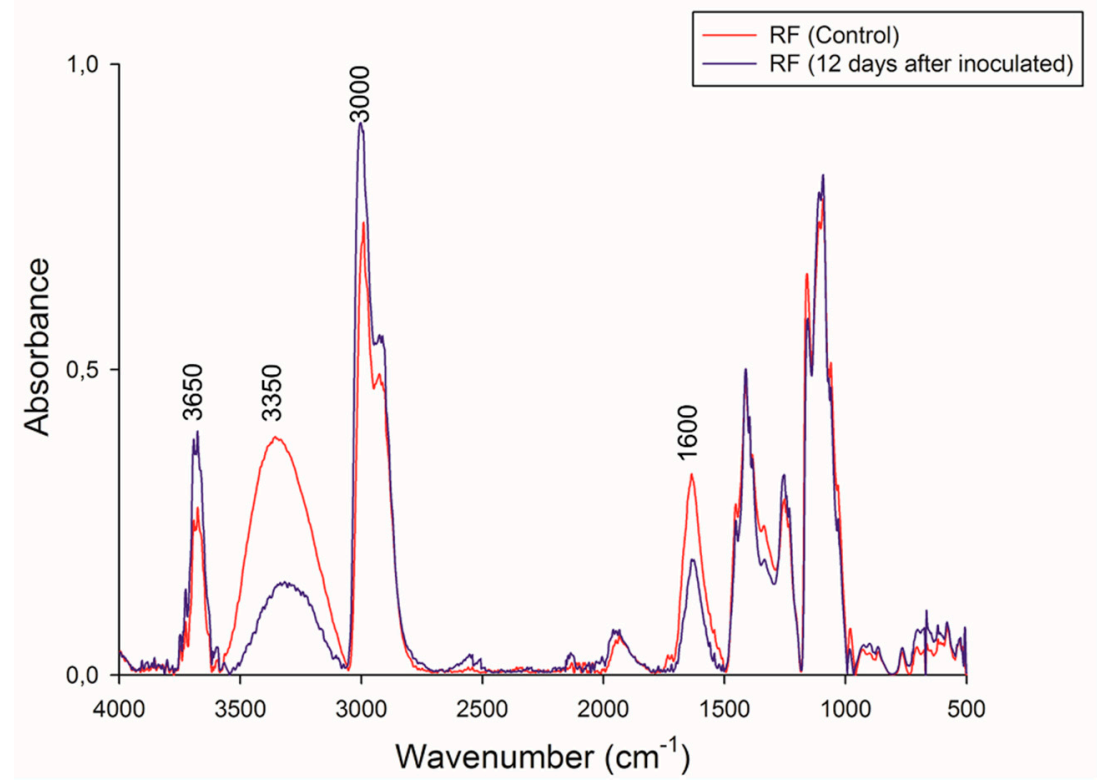

Figure 7. FT-IR spectral of initial and final biomass. Red line: RF control, and black line: residual RF 12 days.

Both spectra showed a broad peak in the $\mathrm{OH}$ stretching region at $3350 \mathrm{~cm}^{-1}$. This band is associated with the hydroxyl groups of insoluble fiber present in the RF. In the residual RF spectra, 
a decrease in the intensity of this band indicates the degradation of compounds that possess $-\mathrm{OH}$ moieties (mainly starch, phenols, and cellulose).

The differences in band intensities at 2800 and $3000 \mathrm{~cm}^{-1}$ can be attributed to variations in the amounts of amylose and amylopectin [63] and agree with the TGA analysis mentioned above. The reduction of band intensities may be associated with the lower exposure of the $-\mathrm{CH}$ groups of amylose and amylopectin at the beginning of CBP due to RF compaction.

A decrease at $1600 \mathrm{~cm}^{-1}$ was also observed. Different groups can be associated with this band, e.g., amides, carboxyl groups, $\mathrm{C}=\mathrm{C}$ aromatics, lignin, and amino acids $[64,65]$.

\section{Conclusions}

The results obtained in this work revealed that the native $\mathrm{Bm}-2$ strain has the ability to simultaneously produce $\alpha$-amylase and laccase enzymes whit activities of 135 and $40 \mathrm{U} / \mathrm{mL}$, respectively, which are involved in the deconstruction of the polymers present in the ramon flour. This feature allows the use of this fungus in a consolidated bioprocess for ethanol production from B. alicastrum seed flour at a concentration of $13 \mathrm{~g} / \mathrm{L}$. On this basis, $123.4 \mathrm{~mL}$ of pure ethanol could be produced from $1 \mathrm{~kg}$ of flour. The consolidated bioprocess developed in this work does not require the addition of commercial enzymes to hydrolyze the starchy material nor of a nitrogen source during the fermentation stage. In addition to these qualities, the residual biomass, with average protein content of $22.5 \%$, could improve the economic viability of the overall process in terms of the biorefinery concept.

Author Contributions: All the authors contributed to this work. R.T.-T. conceptualization and project administration; E.O.-M. performed the experiments, analyzed the data, and wrote the original draft; R.C.-V. and J.D.-M. formal analysis; L.A.-G. and D.P.-C. data analysis and resources; A.L.-S. provided expertise and resources; P.E.L.-O., H.A.R. and L.F.B.-P. writing, review and editing of the paper.

Funding: This research was funded by the Consejo Nacional de Ciencia y Tecnología (CONACYT) of Mexico through grant 550976, awarded for doctoral studies, CONACYT-SENER Energy Sustainability project No. 254667 and CONACYT Infrastructure project No. 253986.

Acknowledgments: The authors wish to thank Tanit Toledano Thompson, Eng., and Martin Baas, M.Sc., for technical assistance.

Conflicts of Interest: The authors declare no conflict of interest.

\section{References}

1. Azmah, S.; Abdulla, R.; Hajar, S.; Azhar, M.; Marbawi, H.; Azlan, J.; Ravindra, P. A review on third generation bioethanol feedstock. Renew. Sustain. Energy Rev. 2016, 65, 756-769.

2. Zabed, H.; Sahu, J.N.; Suely, A.; Boyce, A.N.; Faruq, G. Bioethanol production from renewable sources: Current perspectives and technological progress. Renew. Sustain. Energy Rev. 2017, 71, 475-501. [CrossRef]

3. Zhao, Y.; Damgaard, A.; Christensen, T.H. Bioethanol from corn stover-A review and technical assessment of alternative biotechnologies. Prog. Energy Combust. Sci. 2018, 67, 275-291. [CrossRef]

4. Anderson, S.T. The demand for ethanol as a gasoline substitute. J. Environ. Econ. Manag. 2012, 63, 151-168. [CrossRef]

5. Balat, M.; Balat, H.; Öz, C. Progress in bioethanol processing. Prog. Energy Combust. Sci. 2008, 34, 551-573. [CrossRef]

6. Naresh, M.; Rajarathinam, K.; Senniyappan, R.; Moorthy, T.; Kumar, R. Choice of Pretreatment Technology for Sustainable Production of Bioethanol from Lignocellulosic Biomass: Bottle Necks and Recommendations. Waste Biomass Valoriz. 2019, 10, 1693-1709. [CrossRef]

7. Manochio, C.; Andrade, B.R.; Rodriguez, R.P.; Moraes, B.S. Ethanol from biomass: A comparative overview. Renew. Sustain. Energy Rev. 2017, 80, 743-755. [CrossRef]

8. Mihajlovski, K.; Radovanović, Ž.; Carević, M.; Dimitrijević-Branković, S. Valorization of damaged rice grains: Optimization of bioethanol production by waste brewer's yeast using an amylolytic potential from the Paenibacillus chitinolyticus CKS1. Fuel 2018, 224, 591-599. [CrossRef] 
9. Sun, J.; Wang, J.; Tian, K.; Dong, Z.; Liu, X.; Permaul, K.; Singh, S.; Prior, B.A.; Wang, Z. A novel strategy for production of ethanol and recovery of xylose from simulated corncob hydrolysate. Biotechnol. Lett. 2018, 40, 781-788. [CrossRef]

10. Xu, Q.-S.; Yan, Y.-S.; Feng, J.-X. Efficient hydrolysis of raw starch and ethanol fermentation: A novel raw starch-digesting glucoamylase from Penicillium oxalicum. Biotechnol. Biofuels 2016, 9, 216. [CrossRef]

11. Szambelan, K.; Nowak, J.; Szwengiel, A.; Jeleń, H.; Łukaszewski, G. Separate hydrolysis and fermentation and simultaneous saccharification and fermentation methods in bioethanol production and formation of volatile by-products from selected corn cultivars. Ind. Crops Prod. 2018, 118, 355-361. [CrossRef]

12. Wilkinson, S.; Smart, K.A.; James, S.; Cook, D.J. Maximising high solid loading enzymatic saccharification yield from acid-catalysed hydrothermally-pretreated brewers spent grain. Biofuel Res. J. 2016, 3, 417-429. [CrossRef]

13. Jadidzadeh, A.; Serletis, A. The global crude oil market and biofuel agricultural commodity prices. J. Econ. Asymmetries 2018, 18, e00094. [CrossRef]

14. Tanimura, A.; Kikukawa, M.; Yamaguchi, S.; Kishino, S.; Ogawa, J.; Shima, J. Direct ethanol production from starch using a natural isolate, Scheffersomyces shehatae: Toward consolidated bioprocessing. Sci. Rep. 2015, 5, 9593. [CrossRef] [PubMed]

15. Raftery, J.P.; Karim, M.N. Biomass and Bioenergy Economic viability of consolidated bioprocessing utilizing multiple biomass substrates for commercial-scale cellulosic bioethanol production. Biomass Bioenergy 2017, 103, 35-46. [CrossRef]

16. Singh, N.; Mathur, A.S.; Gupta, R.P.; Barrow, C.J.; Tuli, D.; Puri, M. Enhanced cellulosic ethanol production via consolidated bioprocessing by Clostridium thermocellum ATCC 31924. Bioresour. Technol. 2018, 250, 860-867. [CrossRef]

17. Den Haan, R.; van Rensburg, E.; Rose, S.H.; Görgens, J.F.; van Zyl, W.H. Progress and challenges in the engineering of non-cellulolytic microorganisms for consolidated bioprocessing. Curr. Opin. Biotechnol. 2015, 33, 32-38. [CrossRef]

18. Amore, A.; Faraco, V. Potential of fungi as category I Consolidated BioProcessing organisms for cellulosic ethanol production. Renew. Sustain. Energy Rev. 2012, 16, 3286-3301. [CrossRef]

19. Kamei, I.; Hirota, Y.; Mori, T.; Hirai, H.; Meguro, S.; Kondo, R. Direct ethanol production from cellulosic materials by the hypersaline-tolerant white-rot fungus Phlebia sp. MG-60. Bioresour. Technol. 2012, 112, 137-142. [CrossRef]

20. Gilmore, S.P.; O'Malley, M.A. Microbial communities for bioprocessing: Lessons learned from nature. Curr. Opin. Chem. Eng. 2016, 14, 103-109.

21. Okamoto, K.; Nitta, Y.; Maekawa, N.; Yanase, H. Enzyme and Microbial Technology Direct ethanol production from starch, wheat bran and rice straw by the white rot fungus Trametes hirsuta. Enzym. Microb. Technol. 2011, 48, 273-277. [CrossRef] [PubMed]

22. Okamura, T.; Ogata, T.; MINAMOTO, N.; Takeno, T.; Noda, H.; Fukuda, S.; Ohsugi, M. Characteristics of wine produced by mushroom fermentation. Biosci. Biotechnol. Biochem. 2001, 65, 1596-1600. [CrossRef] [PubMed]

23. Okamoto, K.; Imashiro, K.; Akizawa, Y.; Onimura, A.; Yoneda, M.; Nitta, Y.; Maekawa, N.; Yanase, H. Production of ethanol by the white-rot basidiomycetes Peniophora cinerea and Trametes suaveolens. Biotechnol. Lett. 2010, 32, 909-913. [CrossRef] [PubMed]

24. Kudahettige, R.L.; Holmgren, M.; Imerzeel, P.; Sellstedt, A. Characterization of Bioethanol Production from Hexoses and Xylose by the White Rot Fungus Trametes versicolor. BioEnergy Res. 2012, 5, 277-285. [CrossRef]

25. Pérez-Pacheco, E.; Moo-Huchin, V.M.; Estrada-León, R.J.; Ortiz-Fernández, A.; May-Hernández, L.H.; Ríos-Soberanis, C.R.; Betancur-Ancona, D. Isolation and characterization of starch obtained from Brosimum alicastrum Swarts Seeds. Carbohydr. Polym. 2014, 101, 920-927. [CrossRef] [PubMed]

26. González-Hernández, O.; Yoisura-Vergara, S.; Saavedra-Larqué, A. Primeras etapas de crecimiento de Brosimum alicastrum Sw. en Yucatán. Rev. Mex. Cienc. For. 2014, 6, $28-48$.

27. Hernández-González, O.; Vergara-Yoisura, S.; Larqué, S.A. Studies on the productivity of Brosimum alicastrum a tropical tree used for animal feed in the Yucatan Peninsula. Bothalia J. Bothanical Life Sci. Res. 2014, 44, 70-81. 
28. Olguin-Maciel, E.; Larqué-Saavedra, A.; Pérez-Brito, D.; Barahona-Pérez, L.F.; Alzate-Gaviria, L.; Toledano-Thompson, T.; Lappe-Oliveras, P.E.; Huchin-Poot, E.G.; Tapia-Tussell, R. Brosimum alicastrum as a novel starch source for bioethanol production. Energies 2017, 10, 1574. [CrossRef]

29. Tapia-Tussell, R.; Pérez-Brito, D.; Rojas-Herrera, R.; Cortes-Velazquez, A.; Rivera-Muñoz, G.; Solis-Pereira, S. New laccase-Producing fungi isolates with biotechnological potential in dye decolorization. Afr. J. Biotechnol. 2011, 10, 10134-10142.

30. Favaro, L.; Viktor, M.J.; Rose, S.H.; Viljoen-bloom, M.; van Zyl, W.H.; Basaglia, M.; Cagnin, L.; Casella, S. Consolidated Bioprocessing of Starchy Substrates Into Ethanol by Industrial Saccharomyces Cerevisiae Strains Secreting Fungal Amylases. Biotechnol. Bioeng. 2015, 112, 1751-1760. [CrossRef]

31. Ahmed, S.A.; Mostafa, F.A.; Ouis, M.A. Enhancement stability and catalytic activity of immobilized $\alpha$-amylase using bioactive phospho-silicate glass as a novel inorganic support. Int. J. Biol. Macromol. 2018, 112, 371-382. [CrossRef] [PubMed]

32. Miller, G.L. Use of dinitrosalicylic acid reagent for determination of reducing sugar. Anal. Chem. 1959, 31, 426-428. [CrossRef]

33. Johannes, C.; Majcherczyk, A. Natural mediators in the oxidation of polycyclic aromatic hydrocarbons by laccase mediator systems. Appl. Environ. Microbiol. 2000, 66, 524-528. [CrossRef] [PubMed]

34. Lachance, M.-A. Yeast communities in a natural tequila fermentation. Antonie Van Leeuwenhoek 1995, 68, 151-160. [CrossRef]

35. Bradford, M.M. A rapid and sensitive method for the quantitation of microgram quantities of protein utilizing the principle of protein-dye binding. Anal. Biochem. 1976, 72, 248-254. [CrossRef]

36. Holm, J.; Björck, I.; Drews, A.; Asp, N. A rapid method for the analysis of starch. Starch-Stärke 1986, 38, 224-226. [CrossRef]

37. Ruiz, H.A.; Silva, D.P.; Ruzene, D.S.; Lima, L.F.; Vicente, A.A.; Teixeira, J.A. Bioethanol production from hydrothermal pretreated wheat straw by a flocculating Saccharomyces cerevisiae strain-Effect of process conditions. Fuel 2012, 95, 528-536. [CrossRef]

38. Shanavas, S.; Padmaja, G.; Moorthy, S.N.; Sajeev, M.S.; Sheriff, J.T. Process optimization for bioethanol production from cassava starch using novel eco-friendly enzymes. Biomass Bioenergy 2011, 35, 901-909. [CrossRef]

39. Kamei, I.; Hirota, Y.; Meguro, S. Direct Fungal Production of Ethanol from High-Solids Pulps by the Ethanol-fermenting White-rot Fungus Phlebia sp. MG-60. BioResources 2014, 9, 5114-5124. [CrossRef]

40. Alves, E.; Lucas, G.C.; Pozza, E.A.; de Carvalho Alves, M. Scanning electron microscopy for fungal sample examination. In Laboratory Protocols in Fungal Biology; Springer: Berlin/Heidelberg, Germany, 2013; pp. 133-150.

41. Tapia-Tussell, R.; Pérez-Brito, D.; Torres-Calzada, C.; Cortés-Velázquez, A.; Alzate-Gaviria, L.; Chablé-Villacís, R.; Solís-Pereira, S. Laccase gene expression and vinasse biodegradation by Trametes hirsuta strain Bm-2. Molecules 2015, 20, 15147-15157. [CrossRef]

42. Fillat, Ú.; Martín-Sampedro, R.; Ibarra, D.; Macaya, D.; Martín, J.A.; Eugenio, M.E. Potential of the new endophytic fungus Hormonema sp. CECT-13092 for improving processes in lignocellulosic biorefineries: Biofuel production and cellulosic pulp manufacture. J. Chem. Technol. Biotechnol. 2017, 92, 997-1005. [CrossRef]

43. De Souza, P.M. Application of microbial $\alpha$-amylase in industry-A review. Braz. J. Microbiol. 2010, 41, 850-861. [CrossRef] [PubMed]

44. Blanco, A.S.; Durive, O.P.; Pérez, S.B.; Montes, Z.D.; Guerra, N.P. Simultaneous production of amylases and proteases by Bacillus subtilis in brewery wastes. Braz. J. Microbiol. 2016, 47, 665-674. [CrossRef] [PubMed]

45. Aruna, A.; Nagavalli, M.; Girijashankar, V.; Ponamgi, S.P.D.; Swathisree, V.; Venkateswar Rao, L. Direct bioethanol production by amylolytic yeast C andida albicans. Lett. Appl. Microbiol. 2015, 60, 229-236. [CrossRef] [PubMed]

46. Castoldi, R.; Bracht, A.; Rodriguez, G.; Morais, D.; Luciano, M.; Carvalho, R.; Correa, G.; Aparecida, R.; de Fátima, R.; Muniz, P.; et al. Biological pretreatment of Eucalyptus grandis sawdust with white-rot fungi: Study of degradation patterns and saccharification kinetics. Chem. Eng. J. 2014, 258, 240-246. [CrossRef]

47. Pervez, S.; Aman, A.; Iqbal, S.; Siddiqui, N.N.; Ali, S.; Qader, U. Saccharification and liquefaction of cassava starch: An alternative source for the production of bioethanol using amylolytic enzymes by double fermentation process. BMC Biotechnol. 2014, 14, 49. [CrossRef] 
48. Vasina, D.V.; Mustafaev, O.N.; Moiseenko, K.V.; Sadovskaya, N.S.; Glazunova, O.A.; Tyurin, A.A.; Fedorova, T.V.; Pavlov, A.R.; Tyazhelova, T.V.; Goldenkova-Pavlova, I.V.; et al. The Trametes hirsuta 072 laccase multigene family: Genes identification and transcriptional analysis under copper ions induction. Biochimie 2015, 116, 154-164. [CrossRef]

49. Han, J.R.; An, C.H.; Yuan, J.M. Solid-state fermentation of cornmeal with the basidiomycete Ganoderma lucidum for degrading starch and upgrading nutritional value. J. Appl. Microbiol. 2005, 99, 910-915. [CrossRef]

50. Zapata-Castillo, P.; Villalonga-Santana, M.D.L.; Tamayo-cortés, J.; Rivera-muñoz, G.; Solís-pereira, S. Purification and characterization of laccase from Trametes hirsuta Bm-2 and its contribution to dye and effluent decolorization. Afr. J. Biotechnol. 2012, 11, 3603-3611. [CrossRef]

51. Wang, J.; Suzuki, T.; Dohra, H.; Takigami, S.; Kako, H.; Soga, A.; Kamei, I.; Mori, T.; Kawagishi, H.; Hirai, H. Analysis of ethanol fermentation mechanism of ethanol producing white-rot fungus Phlebia sp. MG-60 by RNA-seq. BMC Genom. 2016, 17, 616. [CrossRef]

52. Xu, Y.; Li, J.; Zhang, M.; Wang, D. Modified simultaneous saccharification and fermentation to enhance bioethanol titers and yields. Fuel 2018, 215, 647-654. [CrossRef]

53. Paschos, T.; Xiros, C.; Christakopoulos, P. Ethanol effect on metabolic activity of the ethalogenic fungus Fusarium oxysporum. BMC Biotechnol. 2015, 15, 15. [CrossRef] [PubMed]

54. Mukherjee, V.; Radecka, D.; Aerts, G.; Verstrepen, K.J.; Lievens, B.; Thevelein, J.M. Phenotypic landscape of non-conventional yeast species for different stress tolerance traits desirable in bioethanol fermentation. Biotechnol. Biofuels 2017, 10, 216. [CrossRef] [PubMed]

55. Radecka, D.; Mukherjee, V.; Mateo, R.Q.; Stojiljkovic, M.; Foulquié-Moreno, M.R.; Thevelein, J.M. Looking beyond Saccharomyces: The potential of non-conventional yeast species for desirable traits in bioethanol fermentation. FEMS Yeast Res. 2015, 15. [CrossRef] [PubMed]

56. Zapata-Castillo, P.; Villalonga-Santana, L.; Islas-Flores, I.; Rivera-Muñoz, G.; Ancona-Escalante, W.; Solís-Pereira, S. Synergistic action of laccases from Trametes hirsuta Bm2 improves decolourization of indigo carmine. Lett. Appl. Microbiol. 2015, 61, 252-258. [CrossRef] [PubMed]

57. Avanthi, A.; Mohan, S.V. Single Pot Bioprocessing For Ethanol Production from Biogenic Municipal Solid Waste. Bioresour. Technol. 2019, 283, 159-167.

58. Viktor, M.J.; Rose, S.H.; van Zyl, W.H.; Viljoen-bloom, M. Raw starch conversion by Saccharomyces cerevisiae expressing Aspergillus tubingensis amylases. Biotechnol. Biofuels 2013, 6, 167. [CrossRef]

59. Sakwa, L.; Cripwell, R.A.; Rose, S.H. Consolidated bioprocessing of raw starch with Saccharomyces cerevisiae strains expressing fungal alpha-amylase and glucoamylase combinations. FEMS Yeast Res. 2018, 18, foy085. [CrossRef]

60. Díaz, A.; Bomben, R.; Dini, C.; Viña, S.Z.; García, M.A.; Ponzi, M.; Comelli, N. Jerusalem artichoke tuber flour as a wheat flour substitute for biscuit elaboration. LWT 2019, 108, 361-369. [CrossRef]

61. Escobar, B.; Pérez-Salcedo, K.Y.; Alonso-Lemus, I.L.; Pacheco, D.; Barbosa, R. N-doped porous carbon from Sargassum spp. as metal-free electrocatalysts for oxygen reduction reaction in alkaline media. Int. J. Hydrog. Energy 2017, 42, 30274-30283. [CrossRef]

62. Long, G.; Ji, Y.; Pan, H.; Sun, Z.; Li, Y.; Qin, G. Characterization of thermal denaturation structure and morphology of soy glycinin by FTIR and SEM. Int. J. Food Prop. 2015, 18, 763-774. [CrossRef]

63. Pelissari, F.M.; Andrade-Mahecha, M.M.; do Amaral Sobral, P.J.; Menegalli, F.C. Comparative study on the properties of flour and starch films of plantain bananas (Musa paradisiaca). Food Hydrocoll. 2013, 30, 681-690. [CrossRef]

64. Silva, T.A.L.; Zamora, H.D.Z.; Varão, L.H.R.; Prado, N.S.; Baffi, M.A.; Pasquini, D. Effect of steam explosion pretreatment catalysed by organic acid and alkali on chemical and structural properties and enzymatic hydrolysis of sugarcane bagasse. Waste Biomass Valoriz. 2018, 9, 2191-2201. [CrossRef]

65. Gupta, B.S.; Jelle, B.P.; Gao, T. Application of ATR-FTIR spectroscopy to compare the cell materials of wood decay fungi with wood mould fungi. Int. J. Spectrosc. 2015, 2015, 521938. [CrossRef]

(C) 2019 by the authors. Licensee MDPI, Basel, Switzerland. This article is an open access article distributed under the terms and conditions of the Creative Commons Attribution (CC BY) license (http://creativecommons.org/licenses/by/4.0/). 